\title{
The Role of MUI's GANAS ANNAR as a Religious Institution to Eradicate Illegal Circulation of Narcotics in Indonesia
}

\author{
Yusuf Muhammad Said \\ Law Department, Institute Business Law and Management (IBLAM), Jakarta, Indonesia \\ Email: theo217@yahoo.com
}

How to cite this paper: Said, Y. M. (2021). The Role of MUI's GANAS ANNAR as a Religious Institution to Eradicate Illegal Circulation of Narcotics in Indonesia. Beijing Law Review, 12, 1059-1076. https://doi.org/10.4236/blr.2021.124054

Received: September 17, 2021

Accepted: November 23, 2021

Published: November 26, 2021

Copyright ( 2021 by author(s) and Scientific Research Publishing Inc. This work is licensed under the Creative Commons Attribution International License (CC BY 4.0).

http://creativecommons.org/licenses/by/4.0/

Open Access

\begin{abstract}
The Indonesian Ulema Council (MUI) as one of the non-government institutions (NGOs) was established on the initiative of the 2nd President of the Republic of Indonesia, Suharto, who wanted a single forum for ulama, and figures from religious organizations such as Muhammadiyah and Nahdhatul Ulama (NU). MUI was established on July 26th 1975, on 53 prominent Muslim clerics and representatives from the government to form a single forum for Muslims. The gathering of the ulama was used as the government's partner, the function of which was to provide advice to Muslims to jointly support development, including eradicating the illicit trafficking of narcotics, agreeing to the death penalty for dealers and producers, in addition to preventing ideological conflicts, among orthodox Moslem. The writing method uses normative juridical, without leaving the historical aspects of the founding of MUI and Ganas Annar, normative, or doctrinal, research collects secondary and tertiary data, as well as codified expert opinion, statutory regulations, then is analyzed with the theory of Hans Kelsen, positive law (General Law). The purpose of the research, theoretically to provide an understanding eradication of illegal drug trafficking in Indonesia involves the role of religious institution (MUI) as a forum for Muslim leaders. As a result, MUI as an NGO institution has an appeal (fatwa) containing advice and suggestions. In the Indonesian constitutional system, fatwas do not enter positive law in the theory of state power. Even so, the government still considers the importance of the existence of these NGOs as partners in combating illicit narcotics trafficking, such as a fatwa giving the death penalty to drug dealers or producers who are judged to be in accordance with Islamic jurisprudence.
\end{abstract}

\section{Keywords}

Drug, Fatwa, Law, MUI, Narcotics, Trafficking 


\section{Introduction}

Religious institutions in Indonesia are the same as community institutions (NGOs). The literature in Black's Law states, "An established organization, esp one of public characters, such as facility for the treatment of mentally disabled person" (Garner, 1999).

An institution established by a person or group is intended for the public interest, whether related to matters of religion, health, or environmental protection on an ongoing basis. These public institutions can be established by the state on orders from the law. Such institutions are called state institutions whose management is born through people's taxes.

Meanwhile, institutions that are founded on the awareness of individuals and groups to fight for the good of the wider community are called non-governmental organizations (NGOs) because the operational costs and the appointment of administrators are independent in accordance with general norms.

The Indonesian Ulama Council (Indonesian: Majelis Ulama Indonesia/MUI), as a non-governmental organization (NGO), has an important role in building people who are more tolerant with fellow believers and are more disciplined in their work, as well as obeying both religious and state regulations, such as the prohibition of consuming narcotics or other addictive substances. The ulama are generally believed to be the heirs of the prophet, (waratsatul anbiya) or people who ask questions about religion and can teach life in a civilized, fair, and honest manner. Therefore, the ulama who are members of a single forum of ulama, want to create a "civil" society in Indonesia, namely a society that runs an accountable democratic system, through the implementation of honest and open elections, as well as implementing fair laws. Civil society is not only the dream of ulama but also the international community (civil society). Law No. 17 of 2013, concerning Community Organizations/NGOs regulates the scope of the role of community organizations, (ORMAS) including requiring Pancasila ${ }^{1}$ as the basis of their organization, which was only born 38 years after MUI was established.

MUI was established on July 261975 at the initiative of the 2nd President of the Republic of Indonesia Suharto, who wanted a single forum for ulama from government figures, ulama, and representatives from religious organizations such as Muhammadiyah, and Nahdhatul Ulama (NU) to assist the government's tasks which are not all tasks can be realized by government officials (Wibowo, 2018). Suharto's goal was to encourage the establishment of the MUI in order to reduce factions like in many Muslim countries, in addition to facilitating coordination in building a better ummah. The government's task that has not been optimally implemented is eradicating social diseases, including the circulation of "Pancasila" consists of "Panca" and "Sila". "Panca" means "five", and "sila" means "principle" or "foundation". Pancasila as the ideology of the Indonesian nation and state as stated in the Preamble to the 1945 Constitution as the basis of the Unitary State of the Republic of Indonesia must be implemented continuously in the life of the nation and state. The Pancasila mentioned in the Preamble to the 1945 Constitution are: first, Belief in One God, second, Just and Civilized Humanity, third, Indonesian Unity, fourth, Democracy Led by Wisdom in Deliberation/Representation, and fifth, Social Justice for All Indonesian People (Nugroho, 2021). 
narcotics and other addictive substances, in Indonesia every year continues to increase. Law (UU) No. 35 of 2009 concerning Narcotics, has provided guidelines and severe sanctions for producers, dealers, and users, but the facts on the ground are dealers are not afraid even though the maximum sanctions are life imprisonment and capital punishment.

The task of eradicating narcotics trafficking was handed over to the Indonesian National Police and the National Narcotics Agency (BNN). Facts in the field, the number of circulating cases, and the number of people suspected of having increased for four consecutive years.

The number of narcotics trafficking during 2010-2014 experienced a significant increase, namely the number of narcotics cases in 2010 as many as 17,384 cases with 23,900 suspects, an increase to 19,045 cases with 25,154 suspects, in 2011, and 25,154 cases while 18,977 people suspected in 2012. In 2013 the number of cases was 21,119 cases with a total of 28,543 suspects and in 2014 there were 22,750 cases with 30,496 suspects (Puji Hariyanto, 2018).

BNN said it was able to reduce the prevalence of people who are addicted to narcotics, in the last two or three years, but the number of arrests has actually increased, and this is a threat to the higher society. Citing the World Drug Report (UNODC) BNN said that in 2020 there were 269 million people in the world infected with narcotics abuse, up 30 percent from 2019. World narcotics circulation that makes Indonesia a "big" market target requires BNN to be more prepared and firmer in taking action against narcotics abusers. In 2020, BNN confiscated 1.12 tons of narcotics, 2.36 tons of marijuana leaves, and 340,357 ecstasy pills, in addition to destroying 30.5 hectares of marijuana land or as many as 213,045 stems that had been planted by producers and dealers.

Narcotics crime is included in the international crime organization, which is an internationally organized crime. Indonesia includes extraordinary crimes, namely extraordinary crimes because the dangers are the same as corruption and terrorism. This crime carries a severe penalty. According to Fransiska Novita's research, $50 \%$ of the number of people in prison is involved in narcotics crimes.

The crime has already entered the level of teenagers, students, and housewives who were initially due to poverty, lack of years of law, and the dangers of drugs themselves (Novita, 2011). The less than the optimal task of the Indonesian Police and the National Narcotics Agency has encouraged the ulama who are members of the Indonesian Ulema Council, to be determined to create the Ganas Annar ${ }^{2}$ Institution, to tackle the illegal circulation of narcotics. So far, the MUI has issued a fatwa forbidden for the use of narcotics by issuing fatwa No. 53 of 2014 concerning the death penalty for producers, dealers, and dealers. But the fact is, the circulation of narcotics in Indonesia is still high despite the fatwa from the MUI.

${ }^{2}$ Ganas Annar, a subsidiary institution under the Indonesian Ulema Council, was founded by ulama in Jakarta and its surroundings, as a response to the increasing illegal distribution of narcotics that could endanger the survival of the young generation as the successors of the Indonesian nation. 
The illegitimate fatwa on narcotics, and the death penalty for producers and dealers, were not fully responded to positively by Muslims. By establishing the Ganas Annar wing, which was founded on October 26, 2014/1 Muharram 1436 $\mathrm{H}$, it is hoped that it will have a positive impact in efforts to suppress the illicit trafficking of narcotics, in order to save victims who have been targeted by certain individuals.

Ganas Annar will take action, by conducting socialization and collaboration with relevant agencies in overcoming narcotics and rescuing drug victims through rehabilitation houses to be established in various provinces, affiliated with the MUI.

There are two problems, first, does the MUI fatwa in Indonesian constitutional law have binding force? Second, can the creation of the Ganas Annar institution to help eradicate illegal drug trafficking work effectively?

\section{Theoretical Basis}

These two problems can be answered through Hans Kelsen's theory (general theory) which is also elaborated by Mohamad Mahmud MD, in Legal Politics in Indonesia. Hans Kelsen quoting Austin's opinion, "every law or statute is a t." An order is a statement of the will of a person who has the authority to carry out the law or legislation (UU).

Thus, every law that has been agreed upon is an order that must be carried out, without the need to consider the religious, moral, and cultural norms of the local community. General theory, which is also referred to as positive law, only focuses on implementing laws and regulations. By Mahfud MD, citing Nonet and Selznick (toward responsive law) law other than orders can also be used as a tool (legal policy).

The permanent ones have been stated in Article 3 of the 1945 Constitution, which affirms Indonesia as a state of law. while on a periodic basis the President as head of state and government can revoke or amend laws according to his interests because the law is not only a tool but also a political configuration in Indonesia. In its implementation, the government can enable religious institutions (MUI) to help prevent illicit drug trafficking, through the provision of operational funding facilities and other facilities such as office space and other non-binding assistance. This is because Indonesia is a Muslim majority that needs to be involved in realizing order and justice as the goals of the nation and state.

\section{Research Method}

In order to see the behavior, nature, and fatwa of the MUI and the effectiveness of Ganas Annar's institutions, the writing method, normative juridical which covers the hierarchy of statutory and socio-historical regulations, the struggle of the ulama, including legal norms (Muchtar, 2021).

Normative juridical research, or doctrinal research on law, this method em- 
phasizes more on the concept, the law can be viewed as a set of statutory rules that are systematically arranged based on a certain order (Suteki, 2020).

The order in the legislation has the characteristic of vertical and horizontal harmonization and synchronization. For example, the MUI Institution is an institution (NGO) that is subject to the Community Organization Law No. 2 of 2017 as a refinement of Law No. 17 of 2013, Law No. 35 of 2009 on Narcotics, and Law No. 12 of 2011 on the Hierarchy of Legislative Orders aligned with the Indonesian 1945 Constitution as well.

The author collects secondary data, including tertiary. The primary material is in the form of legal norms, documents that have binding power because they are positive law, and the secondary material, the income of experts is contained in books, journals, treatises, and other websites, including tertiary including dictionaries and bibliographies.

All materials were collected and then analyzed qualitatively, to get a more concrete picture of the two problems proposed, namely whether the MUI fatwa is a positive law, binding to the Muslim community, and whether the Ganas Annar institution is effective in combating narcotics in the community.

The description of the problem, the existence of the MUI as an NGO, the fatwas and advice issued do not include positive law, and have no significant impact except as a reinforcement for the implementation of the narcotics-related law, because MUI oversees Muslims in Indonesia, but does not have binding regulatory authority.

The fatwa he issued was only an appeal. Meanwhile, the existence of the Ganas Annar institution is useful as long as it is interpreted as providing counseling or direct advice to narcotics victims who have not yet received optimal legal protection.

\section{Results and Discussions}

The history of the development of Islamic politics in Indonesia can be seen since the entry of the Dutch and Japanese occupations into Indonesia. Since the XV-XVI centuries, the relationship between the Islamic kingdoms in Demak, Central Java, was quite close to the Ottoman Turkish Sultanate, because they wanted to hinder the pace of trade expansion of Europeans, especially the Dutch. The relationship between the Islamic king and the Turkish sultanate, was equal, not fighting for power to dominate each other. This was in contrast to the wishes of European traders and religious missionaries. They want to control or expand their trade. Political relations that have equality or have a vision of Islamic da'wah make relations between the two regions (Demak and Turkey) more stable (Kasori, 2020).

Thus, the Dutch considered that in order to dominate Indonesia, the ulama were important enough to be minimal partners not to be hostile to them because the ulama were role models for loyal followers (or students) who had a broad and fanatical base. The Japanese government did the same thing when they en- 
tered Indonesia. Japan sees the role of the ulama in Indonesia as being careful enough not to face rejection.

This caution was seen in 1942-1945 the Japanese army approved the establishment of an association called Majlisul Islami A'laa Indonesia (MIAI) which later became the Islamic Organization of the Indonesian Muslim Syuro Council (Masyumi) consisting of ulama from the Muhammadiyah faction, Nahdhlatul Ulama. (NU) and other Islamic factions, which in the end, when they wanted to carry out the General Election, each of the Islamic factions separated themselves and formed political parties from each faction (Petrik Matanasi, 2020).

Masyumi figure that is also from the Muhammadiyah faction Dr. Buya Ham$\mathrm{ka}$, encouraged by Suharto to become the Chair of the Indonesian Ulema Council (MUI), was formed for the first time. At that time, Buya Hamka was one of the prominent Muslim intellectuals and intellectuals who had enough charisma and was consistent in fighting for the Islamic movement, even though on the way he left the MUI because he considered that the institution was no longer independent, but co-opted by the Soeharto government.

Therefore, the establishment of the MUI is not solely related to the rampant circulation of narcotics in Indonesia, but the institution created by Suharto so that it can be used as a working partner in realizing development as expected by the New Order government.

MUI is currently much involved in eradicating the narcotics supply. The Indonesian Ulema Council was founded on 17 Rajab 1395 H or July 261975 through a national meeting of ulama in Jakarta. Therefore, the establishment of the MUI cannot be separated from the direction of the 2nd President of the Republic of Indonesia, Suharto, who pushed for a single forum for Muslims to be created because it could overshadow Islam-ic factions in Indonesia.

Soeharto wanted the MUI to focus on structuring Muslims towards civil society, with quality but also driven by its function as a cleric who has an important role, namely providing examples of life, providing religious guidance, and teaching tolerance in a pluralistic country.

The existence of this institution maintains good relations between religious groups as well as relations with the government in carrying out state duties towards a just and prosperous society as contained in paragraph IV of the Preamble to the 1945 Constitution.

"Then from that to form a government of the State of Indonesia that protects the entire Indonesian nation and the entire homeland of Indonesia and to promote public welfare, educate the nation's life and participate in carrying out world order ..."

The duty of the state to protect and prosper the people cannot be created by the government itself, but it is necessary to involve mass organizations such as MUI. Thus, the existence of the institution is needed so that Muslims are united, not in conflict with each other as has happened in other Muslim-populated countries, such as in Syria, Iraq, Libya, and Afghanistan.

These countries have many factions, and it is difficult to reconcile until now 
the economic and political system is less stable which automatically makes it difficult for the state to realize its goal of making its people more prosperous and prosperous as stated by Bentham, the goal of the state is to make its people happy (Bentham, 2013).

In Suharto's New Order take line, he assessed the importance of national stability and national security as the main requirements for sustainable economic growth, so that government policies suppressed things that could hinder development, such as strengthening primordial and traditional ties, including religious ideological ties (Murtopo, 1981).

All factors that can hinder social, political, and security stability should be eliminated as far as possible if they will hinder development. Suharto to the Joko Widodo administration, made MUI a partner of the government in cooperating, fostering Muslims, inviting people to be more tolerant of fellow believers, including those outside their religion.

The government does not want to be disturbed by Islamic factions that are considered disturbing or want to change the ideology of Pancasila so that the freezing of Islamic community organizations, Hizbutahrir Indonesia (HTI) and the Islamic Defenders Front (FPI) were frozen by President Joko Widodo.

Since the government of Soekarno, Suharto to Joko Widodo, the faction of people who want to live up to the Jakarta Charter, there are still lascars. In Karl D Jackson's terminology, the village kyai, orthodox.

Muslims, and hardline Islamic groups "feel" defeated in defending the idea of the Jakarta charter which wants to include seven words, "Belief in One Supreme God by requiring adherents to adhere to Islamic law."

Orthodox Muslims view that the drafting of the Constitution on August 18, 1945, was more monopolized by secular and Islamic nationalist groups such as Soekarno and Muhammad Hatta, therefore they still want to restore an old dream that has not yet been realized (Jackson, 1980).

By cooperating with MUI as a partner, the government facilitates the head office in the capital city and provides operational assistance in various activities.

The provision of operational assistance is stated through Presidential Decree No. 151 of 2014 concerning Funding for MUI Activities. Financial assistance to carry out some of the institution's programs in carrying out their duties and functions. Among his considerations, Indonesia has a Muslim majority population, because the state has a responsibility to help the existence of the MUI to play an active role in maintaining and improving the quality of religion according to the teachings of the Qur'an and the guidance of the Sunnah of the Prophet Muhammad SAW.

Presidential Decree regarding the provision of operational fund assistance through Qq. The 6th President Susilo Bambang Yudhoyono, who is also the former Chief of the Political and Security Staff for the National Armed Forces (TNI), is the Head of the Ministry of Religion and the Regional Head for the regional level MUI. He assessed that the relationship between the government and Islamic organizations such as MUI, Nahddlatul Ulama (NU) and Muhamma- 
diyah, continues to be forged.

As the president, of course, he hopes to get support from the largest Muslim group in the capital sector to work more stable and will get greater support in controlling state policies. That's because, from Suharto to Joko Widodo, his relationship with the MUI was quite good. Even when Susilo Bambang Yudhoyono became president, Chairman of the MUI Ma'ruf Amin, and when Joko Widodo was president, he was invited to become vice president. Institutional and personal relations are quite close, even though in the Indonesian constitution, MUI is only an NGO. Even the fatwa ${ }^{3}$ cannot bind on the community members, including those who adhere to Islamic teachings.

\section{MUI Fatwa Position in Indonesian Law}

Indonesia adheres to the principle of legality. This means that no one's actions can be punished unless there is a law that regulates them. This is stated in the Criminal Code Article 1 paragraph (1). In legal terms, everyone must submit to the rules that have been set by the state, in other words, subject to positive law.

Hans Kelsen in the theory of General Law, states, "law is an order that is coercive. In this context, Kelsen formulated pure law in its implementation to be separated from morality and religion. The law is taken from the basic norms that have been agreed upon by the legislators from the state authorities so that the people just obey what has been decided by the ruler.

Han Kelsen also describes the relationship between natural law and positive law, including the validity of the highest norm values. Norms whose validity cannot be obtained from other forms of a higher level are called basic norms. The basic norm can be used as a binder from other norms.

Indonesia is a country consisting of more than 16,771 islands with an area of approximately $81,000 \mathrm{~km}$ and a coastline that ranks second after Canada. If the founders of independence did not set a basic norm, namely Pancasila as the ground norm, Indonesia would certainly continue to have conflicts because it is difficult to achieve unity.

There are many factions, many religions, many ethnic groups in Indonesia who fight for their views as state ideology such as Islam, Capitalism, Nationalism, and Socialism.

By the first President of the Republic of Indonesia, Soekarno, all of these proposals were just norms whose validity was not strong enough, because each of them would fight over and fight for their wishes. Therefore, on June 1, 1945, Pancasila which consisted of five precepts was born, which was later refined by the Committee of Their Unity to become first, Belief in One Supreme God, second, Just and Civilized Humanity, third, Indonesian Unity, fourth, Democracy led by Wisdom and Deliberation and fifth, Social Justice for All Indonesian People.

Pancasila in German terms, Grundlegendes Fundament, and in it contains re-

${ }^{3}$ In the Indonesian dictionary, the meaning of fatwa is the opinion or advice of a mufti or cleric on a matter related to religion, such as advice, advice, lessons and written decisions or policies. 
ligious norms and civilized humanity. If the Indonesian people can respect religious norms and moral norms as has been done by the Japanese recently, surely the circulation of narcotics in Indonesia can be suppressed. Kento Kobayasi, director of the Tokyo 2020 Olympics Opening Ceremony, was fired by the chairman of the Japanese Olympic Committee over a letter of protest from the Simon Wisienthal Center for the Defense of Jews in the US Kento in 1998 once made a joke in a Japanese television parody program which in es-sence, made fun of the Jews (genocide) when they lost World War II.

The recording of the joke was sent to the Olympic committee, so Committee chairman Seiko Hashimoto apologized and fired Kento Kobayasi from the Tokyo 2020 Olympic committee (Kompas News, 2021).

Likewise, other participants who had violated ethics even though the time was more than 10 years ago, were still asked to step down like Keigo Omayada, a composer of Olympic ceremony music, because he was considered to have hurt or harassed someone with special needs while he was in high school in 1995.

Japan and Indonesia actually both adhere to the civil law legal system, because the law in Japan is heavily influenced by the German state, while Indonesia adopts the law from the Netherlands. But in its development, the implementation of law in Japan is closer to Islamic law, which does not always look at the text, but in context. In Islamic law, expediency is preferred as a reference to provide a way of peace to those who are in conflict or demand justice, such as the crime of stealing or killing. If the claimant (victim) can forgive, my hand will not be cut off or beheaded in retaliation for murder. Court judges are only facilitators of those in conflict. In Japan, the goal of the law is peace, where law enforcement officials often ignore formalities (texts) in the law. Therefore, a person who violates ethics can be fired or forced to resign from public office in order to maintain the peace of those in conflict.

This is different in Indonesia. The purpose of the law is a certainty. Therefore, many people who violate ethics do not want to resign from public office, because they rely on written law (pure law), or only look at the text alone, so many prisons are overcrowded with people being imprisoned, even though their mistakes are small, such as the theft of two watermelons, and other crimes. displeasing to an official or businessman, imprisoned by law enforcement officers, $q$ the police, or the prosecutor's office (Rahman, 2020). Indonesia as a state of the law is understood in a rigid manner and does not often ignore its legal context.

Jimly Assiddiqie said that in Indonesia there are only three state institutions that can make laws, namely, the government, parliament, and courts (judicial institutions).

The government with its variants can make laws and regulations either on orders from the Constitution or on orders from the Act. Likewise, the House of Representatives, as well as the Constitutional Court or the Supreme Court, can make regulations related to their main duties as state institutions.

Law No. 12 of 2011 concerning the Establishment of Legislation in accordance with the 1945 Constitution which was perfected through Law No. 15 of 2019. 
Regarding the Formation of Legislation Article 7 of the Law regulates the order of legislation, namely: 1). 1945 Constitution 2). Decree of the People's Consultative Assembly 3). Law/Regulation in Lieu of Law 4). Presidential decree 5) Provincial regulations 6) Regency/City Regulations.

Apart from the hierarchy of statutory regulations, laws, and regulations issued by RI State Institutions under the orders of the Constitution of the Republic of Indonesia, such as the Supreme Audit Agency, the Supreme Court, and the Constitutional Court, and institutions under the order of the Act, such as other state institutions apply. Each regulation is not allowed to conflict with the laws and regulations above. (Lex superior derogate legi inferior).

The view of Mohammad Khalid Jamalzai, from Afghanistan University, said that Islam has a different character from the rules constructed by humans. The source of Islamic law comes from the creator of man (Khaliq) where some are absolute and some are flexible. Regarding faith in Allah SWT regarding monotheism, it is obligatory to obey it, it is non-negotiable.

However, regarding world law, or Islamic jurisprudence, it is quite open, perhaps only Is-lam gives freedom to humans to freely express themselves. Khalid gave an example, food and drink that are declared haram, call it alcohol and narcotics, can be used by humans if they are used as medicine. Illegal goods can become halal if the conditions are met.

Likewise, halal goods can become haram if the conditions are not met, for example, slaughtering an animal (sheep) that does not recite the prayer "Bismillah ..." mentioning the name of Allah when having sex withoutdoing a marriage process. Even a student or student is justified in disagreeing with his teacher, even though the structure of the teacher or lecturer is of a higher degree of ulamahip. However, if there is a controversy that is difficult to reconcile, the ulama have the obligation to convey their fatwas, ex-press opinions to be heard and followed by the parties.

This is the view of Islam as rahmatan lilalamin, a mercy for every human being because of the freedom to think and be creative, but if there is a problem, it must be returned to the fatwa of the ulama.

Meanwhile, Fatwa is an opinion or advice from a mufti or cleric on a matter related to religion. In the Indonesian dictionary, it is stated that there are 3 meanings, namely advice, lessons, and written decisions or policies.

Giving a haram fatwa on goods containing alcohol or other addictive substances that can be intoxicating for users is the opinion of a mufti on the basis of Islamic jurisprudence. The state needs MUI to help prevent the illegal circulation of drugs, in accordance with one of its duties, encouraging people to act better.

MUI also has aim to encourage people or the community to act better according to Islamic teachings. MUI is part of an NGO. In Indonesian constitutional law, NGO institutions are not included in state institutions, countries that can make regulations that contain legal sanctions or make binding regulations, 
The MUI is only a forum for ulama, whose function is to provide guidance and guidance to Muslims, to provide advice and fatwas regarding religion and society, so the fatwas or regulations that are issued are not included in the applicable laws and regulations.

In essence, the function of MU, as an institution engaged in da'wah, upholding the truth and preventing evil (Amar ma'ruf and nahi Munkar). So that is the basis for making fatwas, the Al-Quran, Hadith, Ijtima, and Qiyas.

The Qur'an comes from revelation (Illahi), while the hadith comes from what was said and done by the Prophet Muhammad SAW, being a reference for fatwas after the Qur'an. The hadith is widely believed because Muslims believe that what Muhammad did was an indication of Allah's revelation. Ijtima' and Qiyas, are interpretations of pious humans. Ijma means the agreement or conformity of the opinion of religious experts regarding a problem at a place at one time. For example, the codification of the Qur'an has been carried out since the companions of Abu Bakar and Usman Bin Affan, the human effort to keep the revelations easy to read and remember by the next generation.

Likewise, the call to prayer for Friday prayers, whether twice or once, can be carried out and does not need to be contradicted because when Rasulullah did both at different times.

Qiyas equates the law of something that has no provisions in the Qur'an and Sunnah with other things whose law is mentioned in the Qur'an and Assunnah because there are similarities, there is a strong cause or reason. For example, Islam forbids drinks containing alcohol. All products or goods, which contain alcohol, are prohibited.

Thus, the source fatwa is not a basic norm (ground norm) that can be used as a positive law by the state, so it does not have coercive power that can be carried out by the state. The fatwa is only a reinforcement, an additional supplement from an NGO that has broad and strong influence and is believed by its followers to bind itself to the provisions of the MUI. Ainun Najib, called it, the fatwa from a group of ulama is only an element of the state infrastructure in Indonesia, not the superstructure of the state (Najib, 2019).

This opinion was reinforced by Jimly Asshidiqie, who distinguished institutions (staat heaven) from Non-Governmental Associations/NGOs. Staat heaven is interpreted as a political institution, it is known as a state institution, state agency, or state organ which also as a council refers to the word institution (Akbar, 2013).

Such state institutions, among others, are contained in Article 23 paragraph (1) referring to the Financial Audit Agency (BPK) which gives a mandate to the agency to conduct an independent audit of state finances. In addition to the BPK, the Constitutional Court (MK) is also contained in Article 7 A paragraph (3-5) which contains, among other things, the Court can dismiss the president on the proposal of $2 / 3$ of the members of the people's representative council.

Institutions in Indonesia as an extension of the state, there are also institu- 
tions formed by order of the law, from Presidential Regulations to Decrees of the Directorate General of a department, including the existence of regional regulations related to regional autonomy. In short, these institutions can make regulations that are coercive and there are sanctions in general.

Riyal Ka'bah argues, Islamic regulation (or shari'ah) which is often echoed by ulama from the past until now, refers more to fiqh (the law that regulates humans, society, and the environment.) Personal responsibility is only to Allah SWT. Fiqh is not included as state law or positive law.

When the Ottoman caliphate of Turkey had not fallen, Islamic law was codified, and it was widely used by Arab countries. The Dutch East Indies government when colonizing Indonesia also absorbed Islamic law in dealing with marriage law, inheritance law, or related to Islamic law (see Mogharraer Code of 1747 which applies in Central Java).

The views of R Kaaba, Islamic sharia, and state law are not the same. The state has rights and responsibilities to its citizens, not literally linking it to God Almighty. Islamic law is limited to individual humans, groups, and the environment associated with accountability to God.

Soekarno admitted, in the 1945 Constitution, it was stated as an emergency law. Soekarno said that the Constitution was short, (flexible) because it was drafted in a short time with a limited number of people. After the independence of Indonesia in 1945, the MPR needed to reformulate to be completer and more detailed in formulating the state foundation or the 1945 Constitution. According to Rifyal, Soekarno's hopes had not yet been able to be realized. In fact, the members of the MPR and DPR seem sacred from the 1945 Constitution so that there is a small possibility that there will be changes to the Constitution which will absorb a lot of the modification of Islamic law as expected by many ulama who are members of the MUI.

Therefore, the MUI fatwa as outlined in various regulations cannot be referred to as positive law as long as it is interpreted to bind all levels of the nation's children because the source is not from heavenly authorities, but NGOs that are considered by the government as working partners, one of which is to overcome the illegal circulation of drugs or addictive substances which can damage the young generation of the Indonesian nation.

The MUI's Malignant Institution Participates in the Eradication of Drugs. The birth of the Ganas Annar institution as an intra-MUI institution, because of the concerns of the ulama, especially the ulama who live in Jakarta and its surroundings over the rampant circulation of narcotics in Indonesia.

On 1 Muharram/1436 H/26 October 2014, it was declared to create an institution that can assist the government, suppressing the illegal circulation of narcotics. The institution is called Ganas Annar, in Sanskrit, meaning a man who is brave to prevent mistakes.

The history of the establishment of the institution quotes Imam Abu Daud and Muslim philosopher Yusuf Qardhawi as saying:

The Messenger of Allah (PBUH) forbade anything that could intoxicate and 
weaken or make a person weak or drunk (Narrated by Abu Dawud). According to Alqardhawi's interpretation, the ban shows a firm and clear command so that Muslims do not consume products that can cause themselves to be drunk. Everyone who uses haram goods will lose his reason because he is drunk, so that person is not allowed to pray, let alone become a prayer priest, including teaching religious knowledge. People who are drunk are forbidden to become priests and perform other deeds even if it looks good. The ulama in Indonesia are concerned about the large number of narcotics trafficking, where the number of users continues to increase despite various government efforts.

The National Narcotics Agency (BNN), established based on Law No. 35 of 2009, as a non-departmental institution under the direct supervision of the president, is tasked with preventing and eradicating narcotics abuse and the like, excluding the use of drugs and scientific research.

In the past seven years, 2011 to 2018, BNN recorded the confiscation of evidence of drug-related assets reached around Rp. 5894 trillion, with a total of 20,470,386 kg of drug evidence consisting of psychotropics, precursors, NPS ketamine, and substances containing other alcohol that can harm humans.

BNN also noted that the reporters from that period, 2011-2018 experienced an up and downtrend, but qualitatively there was an increase. In the last three years, in 2016 there were 883 cases, increased to 1011 cases, and in 2018 decreased to 990 cases of drug-related complaints (BNN, 2018) (Figure 1).

If seen from the graph, it reached 12,445 cases and 16,135 suspects. From the number, there are 10 cases that are quite large.

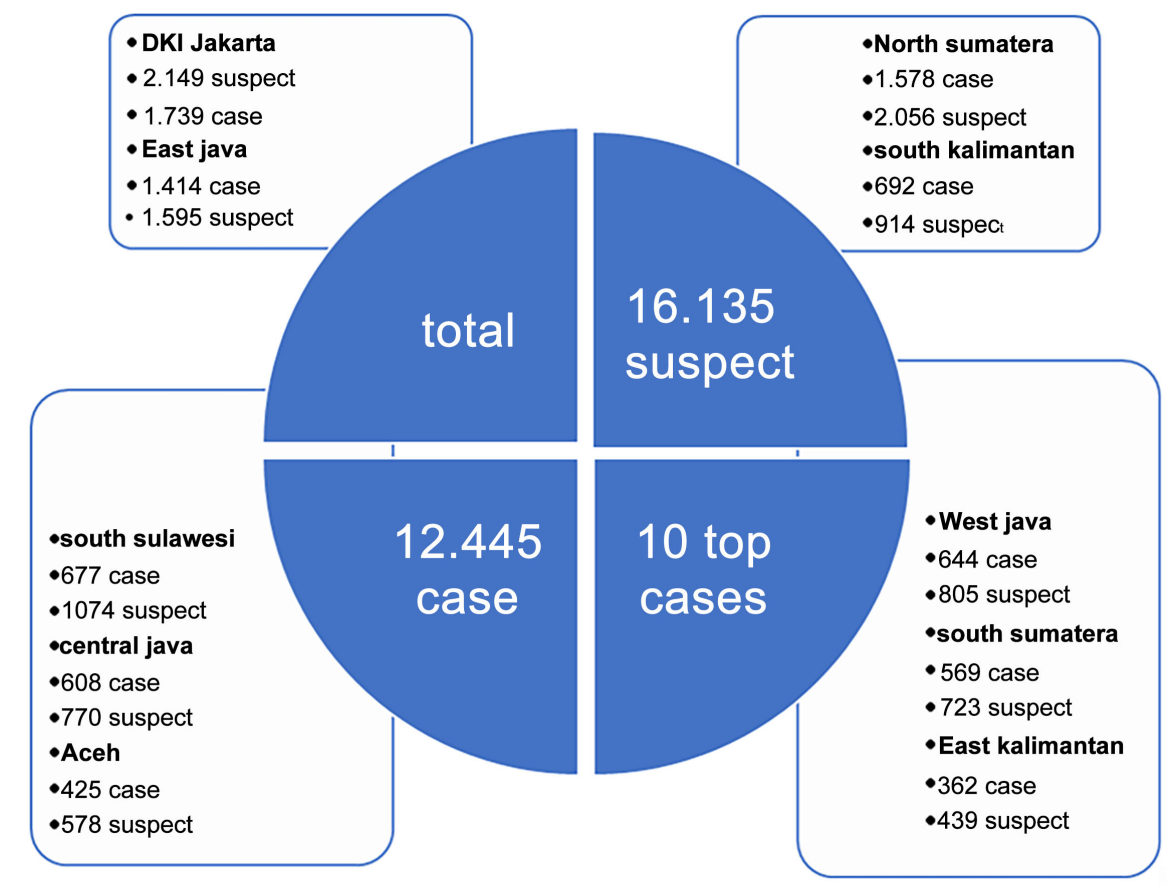

Figure 1. Distribution of narcotics cases by province in Indonesia. 
The distribution of drugs is almost evenly distributed to all provinces in Indonesia, consisting of 34 provinces, of which the largest distribution is in the Java region, which is the most densely populated area. In addition to the population size, there is also the influence of a weak apparatus monitoring system, because not a few officers are involved in the use or trafficking of drugs.

In mid-February 2021, for example, as many as 12 members of the Police from the Astaanyar Police Headquarters, West Java were arrested by police officers from the Regional Police in Bandung, West Java for drug parties caught (Jawa Post, 2021). The incident was considered embarrassing because the Indonesian National Police and the National Narcotics Agency (BNN) were actively carrying out drug eradication, but instead, the police officers themselves carried out the forbidden goods party.

In early May 2021, in East Java, the East Java Regional Police security unit (Propam) arrested 8 people, five of them police officers, and even two of them with officers.

If high-ranking officers and their subordinates as non-commissioned officers carry out cooperation in catching illegal drugs, then the catch is not destroyed and even used for parties. The actions of the officers in the police will make it difficult for the officers themselves because what they are facing is not civil society but colleagues from the same profession. This is the complex problem of eradicating drugs in Indonesia.

For this concern, the Indonesian Ulema Council continued to exert pressure while establishing the Ganas Annar institution, one of its flagship programs conducting counseling through rehabilitation houses to be established in various provinces in collaboration with regional MUI. Ganas Annar's participation in counseling and rehabilitation is carried out with a network of partnerships throughout the region.

Integrated counseling, as an effort to provide assistance to victims of drug addiction by using various counseling approaches and empowering victims to the social environment so that victims immediately become normal, moral members of society and can support themselves and their families.

Noor Sidharta, head of counseling, details the three stages in conducting guidance, namely:

1) Detoxification performed by a doctor. Doctors will perform a number of physical and mental examinations on drug addicts including screening for physical and mental illness infections in drug addicts.

2) Primary or non-medical rehabilitation, namely therapeutic communities, helping patients get to know themselves through personality, emotional, psychological development, including behavior management and seeing the spiritual depth of victims,

3) Advanced development stage, namely drug addicts will be given activities according to their interests and talents. The goal is for them to be able to return to productive activities or work after the rehabilitation program. This counseling 
guidance is used as a flagship program and in practice it is already running, and even the Indonesian Ulema Council facilitates a counseling center in Puncak Bogor to provide counseling guidance.

Members of MUI in areas such as in East Kalimantan are also ready to donate their land for the construction of counseling guidance houses.

With this model, the Ganas Annar program in participating the fight against illegal drugs can be successful as long as it is interpreted as not providing legal sanctions, but providing counseling and medical assistance for victims.

The narcotics industry, in Syaiful Bakhri's view, is a consequence of economic and trade globalization leading to freedom of transaction and investment in various parts of the world. The goal is to make a profit even though the capital used is the result of money laundering, such as drug sales, proceeds of corruption, and other disgraceful acts, such as selling people.

Indonesia is used by narcotics traffickers as the main market considering its population, entrance, and legal system which is relatively weak compared to other countries in the Southeast Asian region.

Through a legal settlement approach, it has experienced a "failure". The law is only applied as a concept of retaliation.

President Richard Nixon has declared war on drugs since 1971, but until now the illegal circulation of drugs in the US has not decreased. Likewise, the Australian Minister of Health said that in the last 40 years ago his party declared war on narcotics, and the crime was included in the extraordinary (extraordinary crime) but the distribution of these goods with a wide variance is still high.

Syaful Bakhri agrees with tackling drug trafficking in Indonesia through community involvement such as the role of Ulama, the role of Religious Organizations, Muhammadiyah, and NU including other civil societies who care about the safety of the nation's children.

Articles 104 and 105 of Law No. 35 of 2009 provide a broad role for the community to participate in the eradication of drugs.

"The community has the widest opportunity to participate and assist in the prevention and eradication of abuse and illicit trafficking of narcotics and narcotic precursors."

Article 105 adds, "The community has rights and responsibilities in efforts to prevent and eradicate abuse and illicit trafficking of narcotics and narcotic precursors."

The two articles are state awareness to involve the community, civil society including non-governmental organizations/NGOs such as MUI-Ganas Annar, the Anti-Drugs Movement, and other NGO institutions, were in the activities of these institutions together with the National Narcotics Agency and the Police to prevent illicit narcotics trafficking.

Syaiful Bakhri, who is also a professor at the University of Muhammadiyah Jakarta, proposed that the eradication of illicit drug trafficking should be integrated through three channels: 
1) Through a harsh punishment approach for producers and distributors, (life imprisonment to the death penalty).

2) Optimizing the participation or participation of civil society and NGO institutions.

3) Growing moral and religious education in family life. In his research, drug users, especially those who are not producers and dealers, are mostly due to a lack of attention to moral and religious education from their close family. This method has not been taken by many countries.

Sanctions for dealers and drug dealers are quite severe in Indonesia, the same as in Singapore. The difference is that in Singapore, gradually and continuously, they want sanctions for narcotics offenses not to be sentenced to death, following what is happening in the European region. European countries in therapy, more directed to counseling, care, and health guidance. This is in accordance with the global conventions agreed upon over the last 30 years (Koman, 2018). Meanwhile, the pattern has not been fully implemented in Indonesia because there are three things, namely, the high number of illegal drug trafficking, and the support from Islamic NGOs for the death penalty to dealers and dealers.

\section{Conclusion}

Soeharto as the 2nd president had the initiative to form MUI in 1975 that aims to combat the Darul Islam movement, a movement that revolts to Government and prevents another similar movement emerged, so it was necessary to create a single forum for the ulama to make it easy directing and controlling the Muslim movement.

To counter this, the Indonesian government, from Suharto to Joko Widodo, made MUI a working partner, especially in eradicating illicit drug trafficking, due to the fact that the number of illicit drug trafficking each year qualitatively continues to increase. The National Narcotics Agency (BNN) said that in the last three years, in 2016 there were 883 cases, increased to 1011 cases, and in 2018 decreased to 990 cases of complaints related to narcotics. Although the MUI is only an NGO that does not have the authority to impose sanctions on its users, it can issue a fatwa, which contains advice, appeals, or advice to Muslims not to use narcotics, as a reinforcement of government action against narcotics.

By postulating the sources of the fatwas from the Al-Quran and the Hadith, they are only a complement to the laws and regulations made by the government and members of the DPR. In accordance with Article 7 of Law Number 12 of 2011 regulating the arrangement of laws from 1945 Constitution outside the hierarchy also applied the regulations issued by the State of Indonesia Institutions at the behest from Indonesian Constitution (lex superior derogate legi inferiori).

The establishment of the Ganas Annar institution under the MUI, in participating in eradicating the illicit trafficking of narcotics has wide benefits for the conversion of users because of the existence of a rehabilitation house to provide 
counseling guidance to users or victims of traffickers. Law No. 35 of 2009 on Narcotics opens a broad role for the community to participate in the eradication of drugs. Counseling, rehabilitation, and health programs for drug addicts, in accordance with international conventions abolish the death penalty for perpetrators. However, Indonesia has not been able to optimize the program because it is stuck with a positive legal view (positivism law), the support of NGOs, the MUI, and the official state agency BNN and the Police are not yet optimal in eradicating illegal drug trafficking.

\section{Conflicts of Interest}

The author declares no conflicts of interest regarding the publication of this paper.

\section{References}

Akbar, P. (2013). Lembaga Negara Menurut UU NKRI 1945 [State Institutions by UU NKRI 1945]. Sinar Grafika Jakarta.

Bentham, J. (2013). The Theory of Legislation (translated by Nurhadi, M. A.). Nuansa Cendekia and Nusa Media.

Garner, B. A. (1999). Black Laws Dictionary(Edited, p. 801). Wes Publishing Co.

Jackson, D. K. (1980). Traditional Authority, Islam, and Rebellion. University of California Press. https://doi.org/10.1525/9780520318212

Jawa Post (2021).

Kasori (2020). Hubungan Turki Utsmani-Demak Abad XV-XVI [Relationship between Utsmani Turkey and Demak in Century XV-XVI]. Dissertation, Sunan Kalijaga State University.

Khalid. M. K. (2020). Al-Azimit and Rukhsat in Islamic law. International Journal for Research in Religious and Cultural Studies, 1, 1-9.

Koman, N. (2018). It Is Not about the Drugs. A Comparative and Contextual Analysis of Singapore and European Drug Approaches. Beijing Law Review, 9, 439-459. https://doi.org/10.4236/blr.2018.93027

Kompas News (2021). Tiada Tempat Untuk Pelanggar Etika [No Rooms for Lawless].

Muchtar, H. (2021). Peraturan Daerah Dengan Hak Asasi Manusia [Regional Law in Human Rights]. Humanus, XIX, 80-90.

Murtopo, A. (1981). Strategi Pembangunan Nasional [Strategic of National Development] (pp. 33-38). Centre for Strategic and International Studies.

Najib, A. (2019). Mendudukkan fatwa Majelis Ulama Indonesia [Establishing the Fatwa of the Indonesian Ulema Council]. Journal of Indonesia Legislation, 16, 290-298.

Novita, F. (2011). Bahaya Narkotika Serta Usaha Penanggulangannya [Danger of Narcotics and How to Prevent]. Jurnal Hukum, XXV, 439-452.

Nugroho, W. (2021). Relationship between Environmental Management Policy and the Local Wisdom of Indigenous Peoples in the Handling of COVID-19 in Indonesia. Oñati Socio-Legal Series, 11, 860-882.

https://doi.org/10.35295/osls.iisl/0000-0000-0000-1193

Petrik Matanasi (2020).

Puji Haryanto, B. (2018). Pencegahan Dan Pemberantasan Peredaran Narkoba Di Indo- 
nesia [Prevention toward Narcotics Supply in Indonesia]. Daulat Hukum, 1, 201-210. https://doi.org/10.30659/jdh.v1i1.2634

Pusat Data dan Informasi (Pusdatin) BNN (2018).

https://puslitdatin.bnn.go.id/portfolio/data-statistik-kasus-narkoba/

Rahman, F. (2020). Perbandingan Tujuan Hukum Indonesia, Jepang dan Islam [Comparative of Law in Indonesia and Japan from Islam Perspective]. Khazanah Hukum, 2, 32-40. https://doi.org/10.15575/kh.v2i1.7737

Suteki, dan Taufan, G. (2020). Metodologi Penelitian Hukum [Law Research Method] (pp. 81-88). RajaGrafindo Persada.

Wibowo, S. (2018). Peran MUI pada masa Orde Baru 1975-1988 dan relevansinya dalam pembelajaran sejarah [The Role of MUI during the New Order Period 1975-1988 and Its Relevance in Learning History]. Candi, 17, 80-95. 